\title{
BAKER v. CARR: HOW TO "SEAR THE CONSCIENCE" OF LEGISLATORS
}

\author{
ALLAN P. SINDLER广
}

THIs commentary is in two parts, one sketching some of the salient characteristics of the apportionment problem, the other offering some early speculations on the implications of Baker v. Carr. ${ }^{1}$ Throughout the first part of this article "equitable apportionment" is judged upon the traditional standard of equality in popular representation. The more equally represented are the voters, the more "equitable" can the apportionment be said to be. Conversely, "malapportionment" sets in at some point-the exact location depending on one's standards-as one moves away from an identical 1:1 ratio of representation among all voters throughout all political subdivisions. The concept of "equitable" becomes appropriately more complex in the second part, where the same considerations that animated the vigorous dissents of Justices Frankfurter and Harlan ${ }^{2}$ in the Baker case are reflected.

\section{Some Pre-Barer Diarensions of the Apportionarent Problezs}

\section{The Omnipresence of Malapportionment in the States}

As of the mid-1950's, the constitutions of about two-thirds of the States included significant restrictions concerning legislative representation which precluded equitable apportionment in one or both chambers. ${ }^{3}$ Some States, for example, provide for a flat equality of area (county or town) representation completely independent of the population factor. Others stipulate, while sometimes paying lip service to the population principle, that each county must have at least one representative, a requirement which, when combined with that of a maximum total of legislators only slightly larger than the total of counties, effectively nullifies the possibility of equitable apportionment. Still other States limit the number of representatives assignable to any one (populous) county. And the obvious escape hatches are closed by provisions which prohibit counties from subdividing themselves in an effort to increase their representation or

$\lceil$ Associate Professor of Political Science, Duke University.

1. 369 U.S. 186 (1962). Since at the time of this writing (late MIay) the outcome of ongoing and projected litigation and legislative activity cannot be known, the discussion on the implications of the Tennessee decision is necessarily speculative.

2. Id. at 266,330 .

3. The data in this and the paragraph following are adapted from BAKER, RURAL versus Urban Polttical Power 11-18 (1955) ; Bosworth, Lawmaking in Slafe Governments, in The Amierican Assearbley, The Forty-Etget States 94-95 (Participants' Edition, 1955) ; Harvey, Reapportionnents of State Legislatures-Legal Requirements, 17 LAw \& Contenspt. Prob. 364-76 (1952); 5 Cong. Q. $172-78$ (1962). There are some slight discrepancies in the data among these sources; these differences are of no consequence to the use made of these materials in this paper. 
which limit the number of counties that may be combined to form a legislative district.

In six of the remaining one-third of the States whose constitutions require a sole reliance on population (or an equivalent standard) as the apportionment base for both houses, legislative failure to reapportion in accord with mandatory constitutional provisions has resulted in seriously inequitable districts. One of these States is Tennessee, whose constitutional standard for apportionment of both chambers is based upon the number of qualified voters, but which has not reapportioned since 1901-with consequences set forth in Baker v. Carr. Failure to reapportion, often called a "silent gerrymander," also aggravates malrepresentation in ten additional States having constitutional provisions for nonpopulation factors in legislative representation. With reference to organic law on legislative apportionment, then, most States play a "heads, I win; tails, you lose" game: constitutional requirements on nonpopulation representation are obeyed, while those on population factors or on reapportionment are ignored.

\section{Party Strength Malapportionment}

Of all States in the mid-1950's, only Massachusetts and Wisconsin had equitable representation in both houses. ${ }^{5}$ To complicate the problem further, however, what may be termed "party strength malapportionment" existed in both of those States. In Massachusetts, partisan gerrymandering by Republicans arranged the district boundaries in such a way as to make Republican popular votes more effective in capturing a proportionately larger number of legislative seats. ${ }^{8}$ In Wisconsin, the play of "natural" forces-the single-member district system and the uneven geographical distribution of party strength -combines to handicap the Democrats in converting their popular-vote strength into proportion of legislative seats won. ${ }^{7}$ Such examples of noncongruency between population and party-strength dimensions of apportionment, which is not confined to the Wisconsin and Massachusetts experience, suggests that the form-

4. See, e.g., dissent of Judge Smith, Scholle v. Hare, 360 Mich. 1, 44 n.4, 104 N.W.2d $63,85 \mathrm{n} .4(1960)$.

5. Baker, Rural versus Urban Political Power 17 (1955). Nonetheless, Wisconsin's post-Baker failure to reapportion in accord with the 1960 census provoked litigation claiming that retention of the 1954 reapportionment structure was invidiously discriminatory to urbanites, particularly Milwaukeeans. When the Democratic governor and the Republicun legislature deadlocked on enactment of a reapportionment measure, the three-judge federal court assumed jurisdiction of the problem and appointed a special master to investigate and to draw up a reapportionment plan for its guidance. See N.Y. Times, July 4, 1962, p. 1, col. 2.

6. It should be noted that gerrymandering, which involves an aggressive act of malapportionment and can take place in the context of equal or unequal population districts, is of lesser importance in state legislative, as distinct from congressional, apportionment. Harvey, Reapportionments of State Legislatures-Legal Requirements, 17 Law \& CoNTEMP. ProB. 368-69 (1952).

7. Epstein, Politics in Wrsconsin 122-25 (1958). 
er may provide an insufficient standard of fairness. The addition of the latter factor, however, greatly complicates the apportionment problem because some modification, if not abandonment, of the single-member district procedure vould have to be undertaken to achieve the goal of equitable party-strength representation.

\section{Some Non-Party Consequences of Malapportionment}

The consequences of malapportionment are necessarily far-ranging because legislative representation constitutes a distribution of political influence and power significantly affecting the operation of the political process and its policy. The most obvious effect stems from the unidirectional distortion of voter equality common to the diverse techniques of malapportionment just noted. The constitutional recognition given to area and other nonpopulation factors has inflated the relative influence of rural voters, and the biases resulting from failure to reapportion, in light of the consistent trends in population movements in the United States in this century, have produced similar consequences. The main victims of legislative malapportionment, until very recent decades, have been urbanites; in contemporary times, suburbanites have joined the ranks of the grossly underrepresented, ${ }^{8}$ and, if current population trends continue, will constitute in the near future the group most discriminated against. ${ }^{\circ}$

Disproportionate rural strength in the national House is limited by automatically reapportioning decennially the number of seats allotted each State. Imbalance in representation can and does occur, however, by action of the state legislature in laying out congressional districts within the State. ${ }^{10}$ Usually only those States gaining several or losing one or more seats find it necessary to redistrict, and gerrymandering is not uncommon in both the initial and any subsequent delineation of district lines. As a result of these factors, the average

8. The most recent thorough analysis of trends in malapportionment of state legislatures is that in Davm \& Eisenberg, Devaluation of the Urbax axi Suburani Vote (1961). A summary statement and tabulation of some of the salient data are presented in 5 CoNg. Q. 170-71 (1962).

9. Baltimore provides a somewhat extreme example of the ongoing urban-suburban contest for chief loser under malapportionment. Though its population grew by over onethird from 1910 to 1960, Baltimore's share of Mlaryland's population declined from slightly over half in 1910 to slightly under one-third in 1960. The degree of inequitable legislative representation to which the central city of Baltimore has been subjected has thus declined over time; conversely, the underrepresentation of the suburban counties around the city of Baltimore has markedly increased in the last two decades. One estimate bas it that Baltimore might be overrepresented by as soon as 1970, thus raising the cynical probability that Baltimore-and other central city areas in the same situation-may at that time align with ruralists to maintain malapportionment practices currently denounced as unjust by urban spokesmen. Lukas, Barmyard Government in Maryland, The Reporter, April 12, 1962, pp. 31-34.

10. The 1929 statute, as amended in 1941 , by which Congress adopted automatic reapportionment, omitted pre-existing provisions requiring House districts to contain approximately equal population and to be composed of compact and contiguous territory. 46 Stat. 26 (1929), as amended, 2 U.S.C. \& 2a (1958). 
rural district population in early 1962 was but eighty-five per cent of that of urban and only two-thirds that of suburban districts. If House representation were based on equally populated districts, then, according to one informed appraisal, about twenty-seven seats would be taken away from rural areas, with three-quarters of them assigned to suburban areas and the remainder to central-city districts. 11

Rural power out of proportion to population strength in the national government is hardly restricted to the rather moderate House distortions just noted. Senate representation testifies to the pure application of the federal principle. And in both chambers, committee, seniority, and other procedures operate to inflate the power of legislators whose constituencies are predominantly one-party in complexion, i.e., rural districts or States, for the most part. Of the existing election procedures, only the mode of presidential election exhibits a strong pro-urban bias, and its retention-in the face of periodic attempts to reform the Electoral College device-may be amply justified as a partial counter-balance to the otherwise omnipresent exaggerated rural influence. ${ }^{12}$

Because of the tainted character of their representative base, State legislatures have contributed to their decline in standing and to the encouragement of attempts to bypass their authority. The prestige of the governor, as the sole representative of a democratic numerical majority, has sharply increased with public awareness that rigged districting and apportionment can convert minorities into legislative majorities. Urban-based interests, wearying of seeking sympathetic treatment from rural-dominated legislatures, have injected their unsatisfied needs and demands into the national arena through such devices as direct aid programs linking the national government and municipalities. There is considerable insight in the view that malapportionment has seriously undercut the viability of the states' rights position and that the achievement of more equitable representation is a necessary precondition for the revitalization of the States in the federal system.

\section{Hobbling An Effective Party System}

The impact of malapportionment on the development of vigorous and competitive State party systems has been notably adverse. The disadvantages have fallen with special force on the Democrats, which testifies, not to their greater morality, but merely to the differential opportunities for imposing malapportionment available to the two major parties.

It should be noted at the outset that the lack of correspondence between a party's proportion of the popular vote for governor and its share of legislative seats won rests to a degree on factors other than malapportionment. For one

11. This appraisal, together with the data in the sentence preceding, are drawn from 5 CoNG. Q. 153-57 (1962).

12. The writer has argued this position more fully elsewhere. See, Sindler, Presidential Election Methods and Urban-Ethnic Interests, 27 LaW \& ConTEMP. Prod. 213 (1962). 
thing, part of the electorate may consciously distinguish between party candidates for governor and legislature, the net effect of which may aggregate on a statewide basis to account for some of the gap between a party's gubernatorial and legislative vote strength. More broadly, the vote for the most important and visible offices, such as that of chief executive (whether president, governor, or mayor) tends to be more volatile than that for legislative posts (whether Congress, State legislature, or city council), thus building in some variance between a party's showing in gubernatorial and legislative contests. Because of its greater stability, the vote for the legislature is a surer index of the longrun party loyalty of a State than is the more fluid gubernatorial vote. By the same token, a minority party aspiring to majority status will customarily capture the gubernatorial office first, then later become able to carry along most to all of the other statewide elective offices simultaneously with the governorship, and only finally, as its strength is firmly established, become able to gain a majority of legislative seats as well. Another factor, noted earlier in the example of Wisconsin, is the extent to which the party's popular strength is distributed in impressive proportion statewide or is narrowly concentrated in sections of the State.

These nonapportionment factors work, for the most part, against the Democrats more than the Republicans, if only because they operate most effectively against the minority party, a status to which the non-Southern Democrats generally had been relegated until the 1930's. They merit attention not only because of their intrinsic importance, but to make clear that not all of a party's inability to secure legislative strength commensurate with its share of the gubernatorial vote derives from institutional arrangements, and the gap would not be fully closed by the introduction of equitable apportionment.

Malapportionment maximizing rural power, however, is the major reason for the incapacity of urban-based Democrats to develop strength in keeping with the timetable noted above to capture legislative majorities with anything like the frequency with which they capture the governorship. Divided party control of executive and legislative branches of State government is thus commonplace in competitive two-party States and a frequent occurrence in predominantly one-party States possessed of a significant minority party; in both groups, Democratic governors face legislatures in which at least one chamber is controlled by the opposition party considerably more often than do Republican governors. ${ }^{13}$ Most political scientists would disapprove of a high rate of divided party control, considered without reference to what brought it about, as detrimental to the political process. With executive and legislative branches controlled by different parties, freer play is given to the negative aspects of the system of power separation, such as friction, passing the buck, and political maneuvering. When, as is so often the case, divided party control stems from apportionment devices designed to block the full expression of the popular will, the critical judgment becomes more emphatically adverse.

13. For a full presentation of the data, see Key, Asrerican State Pourrics: Ars INTroduction 53-64 (1956). See also Bosworth, supra note 3, at 96-98. 
Political scientists, then, would share the broad belief that malapportionment violates democratic values, but would also lay equal stress on the fact that it serves as "a wondrous damper on party government."14 Malapportionment tends to preclude party from performing well such essential functions as structuring political choice for the voters, both as to candidates and policies, and providing incentives to and mechanisms for collaboration between chief executive and legislative majority in a system of checks and balances. Comparable obstacles to the effective functioning of the political party exist elsewhere in the system and would also receive a negative verdict. While the overall oraganization of the Congress, for example, adequately acknowledges the central role of party, adherence to the seniority rule in the assignment of a party's legislators to standing committee chairmanships and memberships tends to diffuse structural power at the direct expense of party leadership, and at the cost of political responsibility and coherent policy. Second thoughts on the direct primary device have leaned to the conclusion that its weakening of party organization and organizational control over the selection of candidates bearing the party's label outweigh, in two-party jurisdictions, whatever benefits flow from maintaining the opportunity for broader rank-and-file participation in the nominating process. By the same reasoning, since divided party control depresses inter-party competition and forecloses even the possibility of developing party government in many States, malapportionment would be considered one of the major institutional defects requiring radical reform.

\section{The Absence of Practicable Solutions}

Paper "solutions" to the malapportionment problem are not hard to come by. A number of mathematical formulae is available to effectuate the goal of apportionment based on the population principle. And a few States already have procedures whereby reapportionment is handled automatically on a periodic basis, thus assuring that representation will be revised in keeping with population shifts. The inability to translate these reforms into law reflects the strategic control of the legislature over the political process. The willingness of legislators, most of whom have a vested interest in retaining the apportionment scheme under which they were elected, to consent to the passage of laws or to alterations to the constitution which would promote more equitable representation has been less than overwhelming. If, as Mr. Justice Frankfurter has urged, "relief must come through an aroused popular conscience that sears the

14. See KEy, op. cit. supra note 13 , at 52 . The term "party government" in this conttext should not be taken to mean the revamping of American parties in the image of a British-styled, tightly disciplined and ideologically oriented party system. Probably as few political scientists currently hold to that perspective as subscribe to the anti-party premises which underlaid the Progressive reforms in the opening decades of this century. "Party government," moderately viewed, simply involves the recognition that organized and enduring parties, when placed in a competitive relationship in their pursuit of political power, are better able than shifting factions, interest groups, or other rivals to perform a number of functions critical to the successful operation of constitutional government. 
conscience of the people's representatives,"15 the prospects of relief remain slim. The initiative device, available in only two-fifths of the States, has been used in several of them to solve the representation problem by bypassing the legislature-but even so, the record is marked more by failure than success. ${ }^{10}$ And the courts, while willing in many jurisdictions to review challenges to affirmative acts of reapportionment, have generally considered it incompatible with the judicial role (the "political question" doctrine) to attempt to compel a legislature to undertake reapportionment in conformity with the state constitutional requirement to do so. ${ }^{17}$

\section{$A$ Rigidity of Attitudes}

Although usually defeated on the battlefields of the State legislatures, opponents of legislative malapportionment have enjoyed a virtual monopoly in ideological warfare. The criterion almost invariably employed by analysts and publicists is that used throughout the first part of this paper, namely, that of approximate mathematical equality of popular representation. In light of evidence from nearly all States, the judgments appropriately become indictments of "misrepresentation," "malapportionment," "inequity," "inequality," and the like. Viewed as a strategy in the conduct of group conflict, this exclusive stress on an equalitarian quantitative definition of the apportionment problem makes excellent sense. If anything said on the problem can "arouse the conscience" of the electorate and can "sear the conscience" of legislators, surely it would be the persistent reiteration of the incompatability of malapportionment with widely-shared democratic values.

Nevertheless, the possession by one side of the controversy of the favored symbols and by the other side of the effective power has not enhanced the quality of dialogue between the two. Many themes meriting serious exploration have tended to go by default, being caught between the extremist single standard of those against malapportionment and the general inarticulateness of those on the other side. For example, the concept of area representation, taken by itself or as the medium for minority interest representation, has no less solid a place than the population principle in democratic values. If the contemporary reliance on counties poorly satisfies the rationale underlying area representation, perhaps more effort should be devoted to devising better methods of implementing the principle and less to discarding it. Again, opponents of malapportionment have paid insufficient attention to the relation of their criterion to the purposes of bicameralism. This is not to say that recent compromises on the apportionment conflict which assign control of one chamber to rural interests and the other to urban interests reveal any better understanding of bicameralism. Might there not be some middle ground between

15. Baker v. Carr, 369 U.S. 186, 270 (1962).

16. For a detailed study of one such recent failure, see Baker, The Politics of Reapportionment in Washington State, in Case Studies in Practical Polmits (1960).

17. Walter, Reapportionnent and Urban Representation, 195 Annals 11, 13 (1933). 
the duplication of the representative base of both chambers and so extreme a differentiation as to promote tendencies to irresponsibility and immobilism latent in bicameralism and the separation of powers? Finally, are rural and urban legislative blocs as cohesive as assumed by both sides, particularly by the supporters of the status quo with reference to urban legislators? The evidence available, as to both the States and the House of Representatives, suggests the far greater influence of party as a determinant of legislative roll-call behavior. Could not the fears of urban-bloc dominance of an equitably apportioned legislature be met by considering ways of assuring significant legislative representation to the minority party in urban areas? By such means the shield of party could be raised against the sword of urban legislators allegedly marching in tight formation. ${ }^{18}$ For reasons that will be made apparent in the second half of the article, however, there is little likelihood that the Baker ruling will stimulate a rethinking of the apportionment problem along lines suggested by the foregoing discussion.

\section{The Likely Implications of the Baker Case}

\section{Doctrinal Inadequacy}

In appraising the Supreme Court's decisions in civil rights cases during its 1960 term, one student has characterized the record as "deeds without doctrines."10 The Court, in this view, scored much higher in terms of restits than in developing "explicit principles rationally justified and applied"20 to reach those results. Such a verdict would be, if anything, too gentle in connection with the recent Tennessee case of Baker $v$. Carr, ${ }^{21}$ decided March 26, 1962. The Court held that a suit challenging the fairness of State legislative representation did not constitute a "political question" and did constitute a justiciable question within the jurisdiction of the courts. The lower federal court was instructed to judge the Tennessee arrangements substantively in accordance with the thinly-developed standard that "invidious discrimination" 22 in a system of legislative representation would violate the equal protection clatse of the fourteenth amendment. The Court's unwillingness to structure the problem more fully for the guidance of the lower courts provoked Mr. Justice Frankfurter's comment that the majority opinion "manifests an odd-indeed an esoteric-conception of judicial propriety."23 It became apparent a month later that the Court's refusal to specify further its criteria was deliberate, when the Court in a brief order instructed the Michigan Supreme Court to give

18. See, in this regard, an instructive study by David R. Derge, Urban-Rural Confict: The Case in Illinois, in WahlKe \& Eulau, Legislative Behavior 218-27 (1959).

19. McCloskey, Deeds Without Doctrines: Civil Rights in the 1960 Term of the Supreme Court, 56 AMr. Poz. Scr. Rev. 71 (1962).

20. Id. at 72 .

21. 369 U.S. 186 (1962).

22. Williamson v. Lee Optical, Inc., 348 U.S. 483, 489 (1955), quoted in 369 U.S. at 245 and 253.

23. Id. at 268 . 
"further consideration in the light of Baker v. Carr"s to the matter of fairness in legislative districts.

In a vigorous dissent in the Baker case, concurred in by Mr. Justice Frankfurter, Mr. Justice Harlan termed the Court's decision "more an adventure in judicial experimentation than a solid piece of constitutional adjudication." The majority, in Mr. Justice Harlan's view, was hoping that state legislatures would take their own cues from the Baker holding and initiate corrective action, thereby relieving the Court of the necessity to confront the complex problem of fixing standards for equitable representation. ${ }^{20}$ If Mr. Justice Harlan's assessment be accurate, then events have confirmed at least the first part of the Court's strategy. Within the short period of seven weeks after Bakcr, there were lawsuits underway in 22 States and being launched in at least six others challenging legislative apportionment. ${ }^{27}$ Because of these suits and the threat of judicial invalidation of the 1962 state election outcomes if present malapportioned systems are retained, many state legislatures have turned with urgency to the task of revising representation schemes to bring them more in line with the population principle. In Georgia, for example, Governor Emest Vandiver called a special legislative session in mid-April to change the countyunit system in a failing effort to persuade a lower federal court of its constitutionality. The court issued its disapproval on April 28, mindful of the fact that the deadline for the filing of candidacies for statewide office in the Democratic primary was May 5.28 Also in late April the Maryland Court of Appeals directed the lower court to rule on the constitutionality of Maryland legislative districts and more than hinted to Governor J. Millard Tawes that it would be in order for him to call a special session of the legislature to reapportion so as to effect "a reasonable relationship of population, or eligible voters, to representation." 29 It seems almost inevitable, therefore, in view of the flood of post-Baker litigation, that the Supreme Court sooner or later must face the hard question of selecting criteria to judge the legality of various legislative arrangements, ultimately, perhaps, "to choose . . . among competing theories of political philosophy."30

24. Scholle v. Hare, 369 U.S. 429 (1962). The constitutionality of Mrichigan's senate districts was upheld by a 5-3 vote in mid-1960, the majority denying the justiciability of the suit in the light of its understanding of pre-Baker doctrine. Scholle v. Hare, 360 Mich. 1,104 N.W.2d 63 (1960). See note 35 infra for the state court's disposition of the case.

25. 369 U.S. at 339.

26. Ibid. Mr. Justice Clark, in concurring with the majority, denied any such aim, likening it to "nothing less than blackjacking the Assembly into reapportioning the State" Id. at 260 .

27. N.Y. Times, May 14, 1962, p. 1, col. 2.

28. N.Y. Times, April 29, 1962, p. 1, col. 6.

29. See A. Krock, N.Y. Times, April 27, 1962, p. 34, col. 5.

30. 'One cannot speak of 'debasement' or 'dilution' of the value of a vote until there is first defined a standard of reference as to what a vote should be worth. What is actually asked of the Court in this case is to choose among competing bases of representation-ultimately, really, among competing theories of political philosophy-in 


\section{Will Judicial Relief Be Available to All States?}

This question is prompted by Mr. Justice Clark's admission, in his concurring opinion in Baker, that "although I find the Tennessee apportionment statute offends the equal protection clause, I would not consider intervention by this Court into so delicate a field if there were any other relief available to the people of Tennessee."31 In reviewing the possible sources of alternative relief, Mr. Justice Clark first mentions that "Tennessee has no initiative and referendum." 32 On the basis of his review of all the possibilities Mr. Justice Clark concludes "that the people of Tennessee are stymied and without judicial intervention will be saddled with the present discrimination in the affairs of their state government." 33

These words can be understood to convey something more than a reluctance to accept the justiciability of malapportionment cases. Turning his point around, it appears to imply that the Court should not deal with malapportionment suits in those States where alternative processes such as the initiative and referendum exist. ${ }^{34}$ If the Court accepts this delimitation, currently twofifths of the States would not be covered by the judicial protection advanced in the Baker case. And doubtless some other States would be happy to accept the implicit invitation to bypass the Baker ruling by adopting such devices.

It is at least questionable whether a Court majority (or Mr. Justice Clark himself, for that matter) would subscribe to such a position. There exists the real possibility that a popular majority might approve adoption of an invidiously discriminatory apportionment system. Such was the case in Michigan, where the apportionment provisions under attack in the Scholle case had been submitted to the voters as a constitutional amendment and endorsed by a majority vote in 1952.35 Moreover, Court denial of the justiciability of malapportionment suits in those States possessed of the initiative and referendum would in no significant way lighten the burden on the Court to implement the Baker ruling in cases involving the remaining majority of States. Moreover, the Court would still have to determine whether the referendum or initiative

order to establish an appropriate frame of government for the State of Tennessec and thereby for all the States of the Union." 369 U.S. at 300 (dissenting opinion of Frankfurter, J.).

31. 369 U.S. at 258.

32. Id. at 259 .

33. Ibid.

34. One can sympathize with Mr. Justice Clark's wish not to involve the courts if the malapportionment controversy could effectively be handled by some alternative routc. It is precisely the unavailability of an alternative that has led those who are "resultoriented" to applaud the Baker decision. And it is the "result-oriented" vicw that constitutes a major target for Mr. Justice Frankfurter, who would substitute for it "a frank acknowledgement that there is not under our Constitution a judicial remedy for every political mischief, for every undesirable exercise of legislative power." Id. at 270.

35. Scholle v. Fare, 360 Mich. 1, 104 N.W.2d 63 (1960). The Michigan Supreme Court ultimately held, by a $4-3$ vote, the senate apportionment provisions to be unconstitutional. Sce N.Y. Times, July 19, 1962, p.14, col. 1. 
were itself infected by malapportionment. Finally, the presence of a referendum without the initiative is useless where the malapportioned legislature itself must submit the issue to the voters. It would seem to be irrelevant that the system of representation happened to have been adopted by popular vote years earlier if the voters no longer have the opportunity to change the system because of a substantial legislative influence in the amending procedure.

Assuming it unlikely that States providing for the initiative and referendum will be treated much differently by the Court, it appears certain that no State can escape the judicial net because of the way its malapportionment may have occurred. The important datum is the result, which will then be measured against the requirements of the equal protection clause, not whether the result came about by State constitutional provision or in defiance of it, by legislative action or inaction, by popular endorsement or by denial of popular control over the determination of representation. ${ }^{36}$ It is an index of the Court's deep involvement in the substance of the apportionment problem that its attention is so focused on results and not on techniques and mechanisms. Variations in the latter thus become irrelevant to judicial protection, and the force of the Baker ruling may be expected to apply to all States.

\section{The Equal-Population Principle}

If one way to put the question is, as Mr. Justice Douglas does in his concurring opinion in Baker, "the extent to which a State may weight one person's vote more heavily than it does another's," ${ }^{37}$ then probably only Justices Douglas and Black might answer, in effect, "to a negligible extent." If a Court majority became persuaded to respond in the same vein, even the most resultoriented opponent of malapportionment would find it difficult to defend the propriety of such a decision. The hard fact is that judicial adherence to the single standard of equal-population representation would constitute an arbitrary choice justified neither by law, nor history, nor logic.

The same judgment does not necessarily apply to judicial support of the equal-population principle as a favored, though not the exclusive, element in a measurement of equitable representation. If both chambers of a State legislature were apportioned in accord with the equal-population principle, no ruralist could reasonably expect the Court to support his claim that the absence of area representation invidiously discriminated against him. But if both chambers were apportioned in accord with a consistent application of area principles, an urbanite could expect the Court to hold that one house, at least, must conform to the equal-population criterion. ${ }^{38}$ For at least the extreme category of

36. Similarly, of course, there appears to be nothing in Baker v. Carr to require a state legislature to reapportion merely because its practices violate its own constitution, if the Court cannot find that "invidious discrimination" has resulted.

37. 369 U.S. at 242.

38. It is pleasant to be able to report that events have supported at least this part of the speculation. A three-judge federal court applied that very principle to the Georgia legislature. N.Y. Times, May 26, 1962, p. 1, col, 6 . 
legislatures which are thoroughly nonrepresentative of population, the Baker holding, then, provides a ready relief without overly inflating judicial power or necessarily involving the Court in a "mathematical quagmire."

It must be admitted, however, that the ease with which the Court could apply the equal-population standard in the foregoing situation derives from the existence of bicameral legislatures. Bicameralism, in this sense, facilitates an escape from the problems raised by Mr. Justice Frankfurter. To confront those problems more directly, one can raise the question, what standard of representation should obtain in a single-chamber legislature? Since an answer to that query is suggested by judicial disposition of litigation on the Georgia county-tnit system, a consideration of that case would be useful at this juncture.

\section{Georgia's Weighting of the Popular Vote}

The Georgia case throws into sharp relief the basis for Mr. Justice Frankfurter's anxieties because it involves the election of statewide officers, a process normally settled by plurality vote of the statewide electorate in the American States, i.e., the pure application of the equal-population principle in the form of "one man, one vote." Georgia, a one-party State in which the general election merely ratifies the critical decision reached earlier in the Democratic primary, conducted its statewide primaries on the basis of a unit system designed to maintain the "rule of the rustics." 30 The unit system was tied to legislative apportionment by law, the number of state representatives being fixed in the State constitution by a three-fold classification of cotuntries by population size. The eight most populous counties had three representatives (and six unit votes) each; the next thirty most populous counties had two representatives (and four unit votes) each; and the remaining 121 counties had one representative (and two unit votes) apiece. The unit vote of each county was awarded to the statewide candidate who secured a popular vote plurality therein; the winner of the primary was the one who gained a plurality of the total unit vote. In the 1960 census, the outermost range of county population was in the ratio of 297:1 (Fulton county, containing Atlanta, compared to Echols county). Since Fulton county was assigned three times the unit vote weight of Echols, the population inequality ratio was reduced to $99: 1$. After the Balicr case, the Georgia legislature, as noted earlier, met in special session to revise the county-unit system. ${ }^{40}$ Fulton county was given twenty times the unit vote strength of Echols, further reducing the population disparity to a ratio of $15: 1$ at the extremes, but rural control was left assured. In addition, a candidate could no longer gain first-primary nomination by garnering a plurality of unit votes, but had to receive a majority of the poptlar vote and the unit vote. If that condition was not met in the first primary, the candidate with the highest unit vote had to contest the one with the highest popular vote in a runoff

39. The phrase is the title of V. O. Key's chapter on Georgia politics in his Soumuens Politics : in State and Nation 106 (1949).

40. See note 28 supra and accompanying text. 
primary, the winner being determined by unit votes alone. It was estimated that about one-sixth of the voters could elect a candidate in the two-man runoff under the revised unit vote system. 11

The three-man federal court unanimously held the new county-unit system invalid under the equal protection clause, but on the basis of standards which lend support to the Frankfurter-Harlan argument. Whatever their own views on the relation of the equal-population principle to the election of the governor and other statewide officials, the judges apparently felt they could not require a State to do more for its counties than the federal constitution required the nation to do for the States in connection with the Electoral College device for electing the president. Accordingly, the use of a county-unit system as such was upheld, and was deemed not to constitute invidious discrimination if, among other things, ". . . the [population] disparity against any county is not in excess of the disparity that exists as against any state in the most recent Electoral College allocation." 42 In contrast to this awkward and varying measure, the same court one month later, in invalidating Georgia's system of legislative representation, was able to offer a straightforward standard: "So long as the Legislature of the State of Georgia does not have at least one house elected by the people apportioned to population, it fails to meet the constitutional requirement." 43 The difference in the standards reflects, as urged earlier, the difficulties in applying the equal-population principle as one moves away from situations of bicameral representation of nonpopulation factors. Significantly, the court did not see fit in the late May case to decide whether, if one house was elected according to population, the other might be based on different considerations.

The quarrel with the court's reliance on the Electoral College model is not primarily that, as of 1960 , the allowable population inequality would be in the ratio of $8: 1$ (eligible voters) or $5: 1$ (population), the comparison in both cases being between Alaska ( 3 electoral votes) and New York ( 45 electoral votes). The complaint is the inappropriateness of the analogy as a substitute for a reasoned standard, however practical the adoption of the analogy may have appeared to the court. Two of Alaska's three electoral votes reflect the nonpopulation factor of equal Senate representation and the third is the counterpart of the minimum of one representative guaranteed to each State regardless of its population size. (Alaska currently has only slightly over half the population of the average congressional district.) Alaska's electoral vote allocation comes to it by virtue not of its population but of its status as a governmental unit (State) in a federal system, yet it is being used to fix permissible population inequalities for counties within the unitary systems of the States.

There is, in the thinking of the court, more than a suggestion of trying to compare apples and lemons. Although the overall electoral vote system is based

41. N.Y. Times, April 29, 1962, p. 55, col. 1.

42. Ibid. In late June, the governing committee of the Georgia Democratic party voted to conduct the primary for governor and other statewide offices on the sole basis of the popular vote. See N.Y. Times, June 28, 1962, p. 37, col. 6.

43. N.Y. Times, May 26, 1962, p. 1, col. 6 . 
mostly on the population factor as translated into the number of representatives assigned to each State, it defers least to the population principle at that end of the continuum represented by such sparsely populated States as Alaska. In fact, it can be said that Alaska gets its electoral votes regardless of or in spite of its population, not because of it. Alaska would have kept its three votes in 1960 had its population been twice or one-half as much as it actually was. ${ }^{44}$ By the court's standard, then, the rate of population growth in Alaska, or in whatever State is least populated, will determine the magnitude of allowable distortion of the equal-population principle in the counties of Georgia. The logical connection between the two variables remains so obscure as to warrant the judgment that the court has come up with a mechanical formula lacking a rational basis.

\section{"Horizontal" Disparities}

Is it any more probable that the Supreme Court will be successful in developing rational standards for determining the discriminatory limits of area or geographic representation in one of the two chambers of state legislatures? A majority of the Court, apparently, would agree with Mr. Justice Harlan that it would not be unconstitutional "if a state legislature's expressed reason for establishing or maintaining an electoral imbalance between its rural and urban population were to protect the State's agricultural interests from the sheer weight of numbers of those residing in the cities." 45 If a legislature could implement that objective in one house by designing a representative system identifiable neither as "capricious" nor "invidiously discriminatory," presumably that system would be upheld in the courts.

In Mr. Justice Clark's opinion, which was the only judgment on the majority side on the merits of the Tennessee system, great if not controlling emphasis is placed on the "horizontal" dimension of discrimination:

Since discrimination is present among counties of like poptlation, the plan is neither consistent nor rational. It discriminates horizontally creating gross disparities between rural areas themselves as well as between urban areas themselves, still maintaining the wide vertical disparity already pointed out between rural and urban. ${ }^{46}$

Primarily because of these "horizontal" disparities, Mr. Justice Clark terms the Tennessee apportionment scheme "a topsy-turvical of gigantic proportions ... a crazy quilt without rational basis." 47

Emphasis on the same point appears in the dissenting opinions of three judges of the Michigan Supreme Court in the earlier case of Schollc $v$.

44. Incidentally, had the latter situation obtained, the inequality ratio would have been $16: 1$ (eligible voters), a disparity larger than that established by the revised Georgla county-unit system.

45. 369 U.S. at 336.

46. Id. at 256 .

47. Id. at 254. What appear as "gross disparities between rural areas themselves" to Mr. Justice Clark, id. at 256, appear to be "nothing in the way of significant discrepancy" to Mr. Justice Harlan. Id. at 335. 
Hare $_{,}{ }^{48}$ those being the only opinions to consider the substance of the suit. The case dealt with a section of the State constitution, approved by popular vote in 1952, which fixed the boundaries of the State senate districts without making provision for subsequent alterations in the light of population change. Thirty-four senate districts were created, in some instances by combining counties and in others by breaking up populous Wayne county, containing Detroit, to form several districts, and each district was assigned one senator. As of 1952, the population disparity among the districts was, at the extreme, $9: 1$, and the disparity was increasing by population movements. Minority rural interests (and the Republican party) were thereby given control of the senate. The dissenting judges "tested" the rationality of the districting arrangements by such criteria as percentage urban, tural non-farm and farm population in each district, number of manufacturing establishments per district, and number of recognized political subdivisions (counties) per district. By these tests, the districts were deemed "arbitrary areas" reflecting no "reasonable or rational classification or criterion" and, therefore, were adjudged to violate the equal protection clause. ${ }^{49}$

It is quite likely that the standard enunciated by the dissenting Michigan judges in Scholle v. Hare and by Mr. Justice Clark in the Baker case would be favorably received by a Court majority seeking ways to distinguish which of the inherently discriminatory effects of geographic representation could be considered an "invidious discrimination." If that came to pass, one probable response by States wanting to retain rural control of one house would be to assign equal legislative strength to each county (or town) and, perhaps, to enlarge the number of counties as well. The chances of a judgment of unconstitutionality would be reduced if States made county representation uniform, rather than attempting to recognize something of the population principle by allocating limited additional representation to some of the more populous political subdivisions.

Judicial invalidation of such an arrangement would run the serious risk of involving the courts further in a "mathematical quagmire" or in the production of formula less than rational. One possible line of judicial attack that would open a new political thicket to confound the courts is suggested by Judge Smith of the Michigan Supreme Court in his dissent in the Scholle case:

It must be stressed that no effort was made by the Mlichigan amendment to apportion according to the existing political units, and thus ve do not reach the question whether or not an historic political unit, once related to the life of the state on a realistic and rational basis, but now largely devoid of people, and representative only of cut-over and despoiled acreage, is a constitutional basis for representation. ${ }^{50}$

48. 360 Mich. 1, 104 N.W.2d 63 (1960).

49. Actually, the Michigan districting was basically a continuation of the pre-1952 representation pattern, itself a product of failure to reapportion. In that respect the background conditions were similar to the Tennessee situation in Baker. See note 35 sipro for the post-Baker decision of the Michigan Supreme Court on the validity of the senate districting arrangements here discussed.

50. 360 Mich. 1, 54, 104 N.W.2d 63, 91 (1960). 
Another judicial position might be an insistence that area representation meet the standard not merely of a consistent application of a rationally-based plan, but that it must also operate within certain population disparity boundaries. Perhaps the Electoral College disparity would be used to define those boundaries or, with equally questionable relevance and markedly less utility, the population disparity in Senate representation (130:1, eligible voters, 1960, Alaska-New York). Whatever the base for arriving at the limits of population inequality in area representation, a justification of it in rational terms is likely to be elusive.

\section{Conclusion}

Contrary to the Frankfurter-Harlan thesis, the post-Baker Court is capable, with a minimum of doctrinal complexity, of putting an end to one flagrant type of malapportionment: subordinating the population principle in both houses of a state legislature. In line with the warnings of the Baker dissenters, however, Court elaboration of criteria of permissible and impermissible forms of area legislative representation (or of area weighting of the popular vote of statewide officials) is likely to be a much stickier problem. In searching for answers to it, the Court may well seize upon Mr. Justice Clark's standard of "horizontal" disparity, a development which would encourage States inclined to maintain rural dominance in one house to give equal representation to its counties. A pronounced legislative pattern in those States thus would become the "fecleral solution," one chamber apportioned according to the equal-population principle and the other in accord with a relatively pure form of area representation. The harmful governmental and party consequences of such an arrangement have been commented on earlier. ${ }^{51}$ The capacity of the Court to prevent stuch a development without injecting inappropriate formulas or arbitrary criteria seems most limited.

It is entirely possible, therefore, that the greatest gains in the struggle against inequitable representation will come from the ongoing whirl of legislative activity in the immediate post-Baker period prior to the Court's implementation of its Baker ruling. Those gains, reflecting legislative reaction beyond what the Baker case ultimately is likely to require, should be politically and judicially irreversible. If that comes to pass, Baker v. Carr can be viewed, as Mr. Justice Harlan charged, as "an adventure in judicial experimentation," but one that succeeded in giving meaning to the otherwise sterile insistence of Mr. Justice Frankfurter that relief from inequitable apportionment "must come through an aroused popular conscience that sears the conscience of the people's representatives." ${ }^{33}$

51. See text accompanying notes 12-14 supra.

52. 369 U.S. at 339.

53. Id. at 270 . 